\title{
Ephrin Receptor
}

National Cancer Institute

\section{Source}

National Cancer Institute. Ephrin Receptor. NCI Thesaurus. Code C18606.

Eph receptor tyrosine kinases and their ligands, the ephrins, appear to lie functionally at the interface between pattern formation and morphogenesis. They play a major role in axonal pathfinding and target recognition during central nervous system (CNS) development. (from Development 1999;126:2033-2044 and Exp Neurol 1999;156:21822) 